\title{
APPLICATION OF THE VIRTUAL BRONCHOSCOPY IN CHILDREN WITH SUSPECTED ASPIRATION OF THE FOREIGN BODY - CASE REPORT
}

\author{
Gordana Kostic $^{1,2}$, Marina Petrovic ${ }^{2,3}$, Slavica Markovic ${ }^{1,2}$, Jasmina Knezevic ${ }^{1,2}$, Zoran Igrutinovic ${ }^{1,2}$, \\ Rasa Medovic ${ }^{1}$, Zorica Raskovic ${ }^{1,2}$, Lidija Stankovic ${ }^{1}$, Predrag Minic ${ }^{4}$ \\ ${ }^{1}$ Clinic for Pediatrics, Clinical Center Kragujevac, Kragujevac, Serbia \\ ${ }^{2}$ Faculty of Medical Sciences, University of Kragujevac, Kragujevac, Serbia \\ ${ }^{3}$ Center for Pulmonary Diseases, Clinical Center Kragujevac, Kragujevac, Serbia \\ ${ }^{4}$ Institute for health protection of mother and child of Serbia "dr Vukan Cupic", Belgrade, Serbia

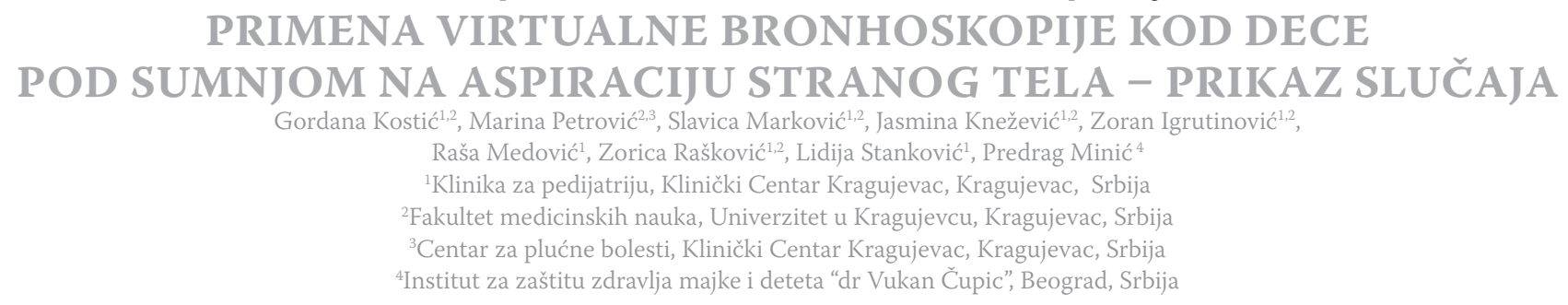

Received / Primljen: 22.03.2016.

Accepted / Prihvaćen: 17.05.2016

\begin{abstract}
In diagnosing the aspiration of the foreign body (AFB) in children most important are: medical history, clinical signs and positive radiography of the lungs. Common dilemmas in the differential diagnosis are life-threatening asthma attacks or difficult pneumonia. Conventional rigid bronchoscopy $(R B)$ is not recommended as a routine method. Virtual bronchoscopy (VB) can be a diagnostic tool for solving dilemmas. Fiber-optic bronchoscopy (FOB) has a therapeutic stake in severe cases. Herein, we describe a girl, at the age of 6, who was hospitalized due to rapid bronchoconstriction and based on the anamnesis, clinical symptoms and physical findings the suspicion was that she aspirated the foreign body. Due to the poor general condition and possible sequel, the idea of $R B$ was dropped out. Multidetector computed tomography of the chest and VB was performed and AFB was not found. Due to positive epidemiological situation, virus H1N1 was excluded. $F O B$ established that the foreign body does not exist in the airways. During bronchoscopy numerous castings are aspirated from the peripheral airways which lead to faster final recovery. With additional procedures, the diagnosis of asthma was confirmed and for girl that was the first attack. Along with inhaled corticosteroids as prevention she feels well.

Virtual bronchoscopy can be successfully used as a valid diagnostic procedure in suspected foreign body in the children's lungs, but fiber-optic bronchoscopy remains most important diagnostic and therapeutic method.

Keywords: asthma, children, foreign body, virtual bronchoscopy.
\end{abstract}

\section{SAŽETAK}

U dijagnostikovanju aspiracije stranog tela (AFB) kod dece najvažniji su: anamneza, klinički znaci i pozitivna radiografija pluća. Česte dileme u diferencijalnoj dijagnozi su po život opasni napadi astme ili teška upala pluća. Konvencionalna rigidna bronhoskopija (RB) se ne preporučuje kao rutinska metoda dok virtuelna bronhoskopija (VB) može biti dijagnostička metoda za rešavanje dilema. Fiberopticka bronhoskopija (FOB) ima terapijskog udela u težim slučajevima. Ovde, opisujemo devojčicu, uzrasta 6 godina, koja je hospitalizovna zbog naglo nastale bronhokonstrikcije i na osnovu anamneze, kliničkih simptoma i fizikalnog nalaza posumnjano je da se radi o aspiraciji stranog tela. Zbog lošeg opšteg stanja i eventualnih komplikacija, odustalo se od RB. Uradena je multidetektor kompjuterizovana tomografija (MDCT) grudnog koša i virtulena bronhoskopija (VB) i AFB nije pronađena. Zbog pozitivne epidemiološke situacije, virus H1N1 je isključen. FOB je utvrdila da strano telo ne postoji u disajnim putevima. U toku bronhoskopije aspirirani su brojni odlivci u perifernim disajnim putevima što je i dovelo do konačnog bržeg oporavka. Dodatnim procedurama devojčici je dijagnostikovana astma $i$ to je bio prvi po život opasan napad. Uz prevenciju sa inhaliranim kortikosteroidima ona je nakon tog napada bila bez tegoba.

Virtuelna bronhoskopija može se uspešno koristiti kao validna dijagnostička procedura kod sumnje na strano telo u plucima kod dece ali fiberoptička bronhoskopija ostaje suverena metoda kako u dijagonstici tako i u njenom terapijskom učinku .

Ključne reči: astma, deca, strano telo, virtuelna bronhoskopija.

\section{ABBREVIATIONS}

AFB - aspiration of the foreign body BDT - bronchodilator test ECP - eosinophilic cationic protein FEV1 - forced expiratory volume in first second FOB - fiber-optic bronchoscopy
IMC - Institute for Health Protection of Mother and Child of Serbia "Dr Vukan Cupic"

MDCT - multidetector computed tomography

RDG- radiography of chest

RB- rigid bronchoscopy

VB - virtual bronchoscopy 